\title{
A organização de um corpo disperso \\ uma análise da atividade jesuítica em terras brasílicas (1583)*
}

MARCOS ROBERTO DE FARIA

Universidade Federal de Alfenas, Alfenas, MG, Brasil

RESUMO

$\mathrm{O}$ artigo investiga a pedagogia da vigilância instaurada pela Companhia de Jesus na segunda metade do século XVI. Com o intuito de organizar o corpo disperso, o centro da Companhia em Roma manda visitar a província do Brasil, a fim de reforçar a vigilância e estabelecer a ordem sobre as coisas. Para verificar essa tese, faz-se uso de uma documentação muito pouco explorada, pesquisada no Archivum Romanum Societatis Iesu (ARSI), em Roma, sobretudo a correspondência entre o visitador e o Geral da Companhia. Nessa direção, o artigo aponta que o reforço da ortodoxia instaurado pela Companhia de Jesus é perceptível em várias direções, como na rígida regulamentação das normas que passam a sistematizar o cotidiano dos colégios e casas que os jesuítas mantinham em terras brasílicas.

\section{PALAVRAS-CHAVE}

jesuítas; pedagogia da vigilância; Contrarreforma; província do Brasil; século XVI.

* Este artigo foi elaborado com base em minha tese de doutorado, defendida em 2009 na Pontifícia Universidade Católica de São Paulo (PUC/SP). Agradeço à Coordenação de Aperfeiçoamento de Pessoal de Nível Superior (CAPES) pela bolsa sanduíche em Roma, que tornou possível o acesso a documentos e textos indispensáveis para esta pesquisa. 


\title{
THE ORGANIZATION OF A DISPERSED BODY: AN ANALYSIS OF THE JESUIT ACTIVITY IN BRAZILIAN LANDS (1583)
}

\begin{abstract}
This article investigates the pedagogy of surveillance established by the Society of Jesus in the second half of the sixteenth century.In order to organize the dispersed body, the Society's headquarters in Rome ordered a visit to the province of Brazil to strengthen surveillance and to establish order. To verify this thesis, we used rarely examined documentation, researched at the Archivum Romanum Societatis Iesu (ARSI), in Rome, especially the correspondence between the visitor and the Society's General. This article suggests that the reinforcement of orthodoxy established by the Society of Jesus is noticeable in several manners, for example, in the strict regulatory standards that were used to systematize daily life in the colleges and houses that the jesuits maintained in Brazil.
\end{abstract}

KEYWORDS

jesuits; pedagogy of surveillance; Counter-Reformation; Province of Brazil; sixteenth century.

\section{LA ORGANIZACIÓN DE UN CUERPO DISPERSO: UN ANÁLISIS DE LA ACTIVIDAD JESUITA EN TIERRAS BRASILEÑAS (1583)}

\section{RESUMEN}

El artículo investiga la pedagogía de la vigilancia establecida por la Compañía de Jesús en la segunda mitad del siglo XVI. Con objetivo de organizar el cuerpo disperso, el centro de la Compañía en Roma manda visitar la provincia de Brasil, para reforzar el control y restablecer el orden. Para verificar esta tesis, se usa un archivo de documentos poco explotado, investigado en el Archivum Romanum Societatis Iesu (ARSI) de Roma, principalmente las cartas entre el visitador y el General de la Compañía. Así, el artículo muestra que el refuerzo de la ortodoxia establecido por la Compañía de Jesús se nota en varias direcciones, como por ejemplo, en la rigidez de las normas que organizan el cotidiano de los colegios y casas que los jesuitas mantenían en tierras brasileñas.

PALABRAS CLAVE

jesuitas; pedagogía del control; Contrarreforma; provincia de Brasil; siglo XVI. 


\section{INTRODUÇÃO}

Certamente é possível afirmar que o século XVI foi marcado por uma crise que se instalou na relação entre religião, poder e relações sociais. Como consequência, pode-se dizer que a Igreja católica lançou mão de vários instrumentos de ordenação, usados para colocar tudo em ordem. Entre esses instrumentos, estava um intenso movimento de organização das práticas dos indivíduos daquele período. Neste artigo, tal movimento de organização é demonstrado por meio das instruções trazidas pelo padre visitador à província do Brasil em 1583 e no embate enfrentado por ele ao se deparar com as práticas no interior dos colégios e das casas que os padres da Companhia de Jesus mantinham no Brasil.

Nessa direção, o artigo pretende aproximar o leitor de práticas estabelecidas pela chamada Contrarreforma e dos instrumentos de vigilância que ela pôs em cena, a fim de discutir as condicionantes históricas que perpassaram a atividade dos inacianos no período. Contudo, a principal contribuição deste artigo está no uso de uma documentação muito pouco explorada, pesquisada no Archivum Romanum Societatis Iesu (ARSI), em Roma. Por meio dessa documentação é possível perceber que a atividade jesuítica foi permeada por conflitos e negociações que se estabeleceram entre os padres, os nativos, os colonos e a direção da Ordem em Roma.

Por conseguinte, o texto destaca o lugar - bastante contestado por Roma e pela sociedade colonial - do jesuíta como administrador das aldeias. No meu entender, a origem dos conflitos está no envolvimento dos padres em questóes temporais, ${ }^{1}$ sobretudo no trato com os nativos nas aldeias. A intenção aqui, entretanto, é proporcionar ao leitor uma nova perspectiva com relação à atuação dos jesuítas na colônia, fundamentalmente porque a fonte de que se faz uso neste artigo é, em grande parte, de difícil acesso para os pesquisadores brasileiros. Sem apresentar conclusões acabadas, o artigo pretende colocar um pouco mais de interrogações com relação a quem eram e o que movia os homens de preto que viveram na terra dos papagaios no início da nossa colonização.

\section{PRIMEIROS EMBATES: É PRECISO QUE SE “META TUDO EM ORDEM"2}

Durante o período no qual padre José de Anchieta foi provincial (cargo máximo entre os jesuítas que trabalhavam no Brasil), realizou-se a segunda visita à província do Brasil. ${ }^{3}$ De acordo com Leite (1938-1949), desde 1574 era pedido

1 Adocumentação jesuítica do período trata das chamadas questões temporais para referir-se ao papel do jesuíta como administrador das aldeias indígenas.

2 Respeito, neste artigo, sempre que possível, a grafia original das publicações de que me valho, inclusive as abreviaturas e a pontuação. Nesse sentido, como a pesquisa foi feita com documentos manuscritos, há algumas reticências nos excertos transcritos ao longo do texto, indicando algum trecho ou palavra incompreensíveis no documento original.

3 A primeira visita à província do Brasil ocorreu em 1566 e teve como visitador padre Inácio de Azevedo. Para conhecer as instruções passadas pelo superior- 
novo visitador para o Brasil e que fosse "pessoa de importância". O indicado para tal empresa foi padre Cristóvão de Gouveia (1542-1622): mestre em artes, natural de Porto, entrou na Companhia no dia 10 de janeiro de 1556. Estudou em Coimbra e Évora e ocupou os cargos de mestre dos noviços e reitor do Colégio de Bragança, da Universidade de Évora e do Colégio de Santo Antão de Lisboa, além de vice-reitor de Coimbra. É considerado, segundo Leite (idem), o segundo fundador da província do Brasil, depois de Nóbrega. Assim, "um dos principais efeitos da Visita do Pe. Cristóvão de Gouveia foi o de promover intenso movimento de informações escritas, pelo seu secretário Fernão Cardim e pelo Pe. Francisco Soares [...]” (idem, p. 279).

O visitador saiu de Lisboa em 5 de março e chegou à Bahia no dia 9 de maio de 1583. Porém, antes de embarcar para a província do Brasil, foi-lhe transmitida uma instrução particular pelo padre-geral Cláudio Aquaviva, ${ }^{4}$ na qual ele declarava o duplo objetivo da visita. Fim principal: para "consolação ${ }^{5}$ dos nossos que trabalham naquela vinha tão estéril, laboriosa e perigosa" (Aquaviva apud Leite, 1938-1949, p. 490). Fim particular: para "ver como se guarda a disciplina religiosa, segundo o Instituto; e o que toca a constituições, regras e obediências de Roma faça se executem, e meta tudo em ordem ${ }^{6}$ quanto as circunstâncias das pessoas e lugares o sofrerem" (idem, ibidem, grifos meus). Dizia-se, continuava o padre-geral,

que os Padres Provincial [Anchieta], Gregório Serrão e Luis da Grã são pouco regulares e pouco dados às Constituiçôes, e que, em geral, os súbditos procedem da mesma forma, frouxa e pouco regularmente. Veja bem isto, que tanto vai, e trabalhe por entender a raiz e o remédio que se pode ter. (idem, ibidem, grifos meus)

Como será possível perceber ao longo deste artigo, o remédio aplicado pelo visitador foi amargo! Repare-se o quanto era clara a determinação de Aquaviva: a visita era para consolar, mas também para vigiar, a fim de que se metesse tudo em ordem. ${ }^{7}$ Penso que é importante frisar esses termos, sobretudo porque destacam, por

-geral da Companhia (doravante Geral), padre Francisco de Borja, ao visitador, conferir Monumenta Histórica Societatis Iesu (MHSI): Monumenta Brasiliae IV [1563-1568], 1960, p. 323-329.

4 De acordo com Assunção (2004, p. 49-50), padre Cláudio Aquaviva foi eleito Geral da Ordem em primeiro escrutínio no ano de 1581. Contava nessa época com apenas 37 anos de idade. Permaneceu no cargo até 1615 . Com atenção voltada para o corpo de missionários, redigiu diversas exortações, instruções e cartas, salientando a importância do progresso da companhia e a necessidade de continuar trilhando os caminhos da perfeição e da renovação do espírito.

5 Segundo Castelnau-L’Estoile (2006, p. 386), a consolação era a essência do processo dessa visita. A consolação é um tema recorrente na espiritualidade inaciana; é uma das moçôes interiores que o praticante dos exercicios espirituais deve aprender a reconhecer em si "desde a primeira semana".

6 Para Hansen (2004, p. 26), ordem é um conceito teológico-político que regula virtude e vício. É nesse sentido que esse conceito deve ser tomado aqui.

7 A primeira visita, de Inácio de Azevedo, teve outro tom, conforme se pode ver na carta reproduzida na sequência, na qual o Geral fez questão de usar a palavra suavidade: "Carta do Pe. Francisco de Borja ao Pe. Inácio de Azevedo, Roma (fim de fevereiro de 1566). Usando de rigor não se esqueça do amor e suavidade. Lo que mucho encomiendo 
assim dizer, o desejo do Geral de organizar o corpo disperso. Bem, mas o que, de fato, estava em desordem? Note que nem mesmo Anchieta, como provincial, escapava da possibilidade de ser averiguado pelo visitador. O que o padre-geral via na província do Brasil era um corpo disperso, que agia de forma frouxa e pouco regularmente. Penso que há muitas razões para que ele fizesse tais recomendações. Entre elas, certamente estava o envolvimento dos padres com questóes temporais e também o fato de muitos estarem se perdendo no trabalho com os índios. As notícias que chegavam a Roma sobre a província do Brasil não eram boas e as cartas revelavam, de fato, que havia muita coisa fora dos eixos, conforme será visto neste artigo.

Além da instrução particular dada por Aquaviva, o visitador vinha munido de uma licença especial, que, conforme compreendo, era carregada de poder: ele era também o homem de confiança da Inquisição. Veja-se a licença que ele trouxe para seus companheiros jesuítas:

Licença do inquisidor-geral dos Reinos e Senhorios de Portugal para se fazer uso de livros proibidos.

O arcebispo de Lisboa, inquisidor-geral nestes Reinos e Senhorios de Portugal, vem fazer saber aos que se apresentem, que pela confiança que temos nos padres $d a$ Companhia de Jesus [...], havemos por bem de dar ao Pe. Visitador da dita Companhia na Província do Brasil que ora estará diante dos superiores dos Collegios da Baía de Todos os Santos, Rio de Janeiro e Pernambuco da mesma Cia [...] para que cada um deles por si, ou por pessoas suficientemente deputadas por eles da dita Companhia possam rever, examinar, censurar todos os livros, opúsculos, tratados, escritos ou papéis ainda que não tenham nome do autor [...] conforme o catálogo tridentino [...] aos 4 de setembro de 1582, Arcebispo. Inquisidor-Geral. (ARSI, Brasilia Epistolae - Bras. 2, fl. 39, grifos meus)

Vale observar que eram os jesuítas quem determinavam o que seria proibido e o que seria permitido. Outro dado interessante que apareceu no texto foi a referência ao catálogo tridentino, numa clara explicitação do quanto o que chamo de pedagogia da vigilância, disposta pelo Concílio de Trento, também chegava por aqui e procurava determinar as práticas do período.

Gouveia trazia consigo o companheiro de visita, Fernão Cardim. Além de Cardim, também fizeram parte da comitiva padre Rodrigo de Freitas e irmão Barnabé Tello. Deixo, então, que o próprio visitador conte sobre sua chegada, sua acolhida e as primeiras providências que tomou:

a V.R. es que mire que sus travajos sean ordenados de manera que merezca durar en ellos para mayor glória divina, y que usando del rigor no se olvide del amor y suavidade que la Compañia usa, a trueco de buscar algunos medios de mayor efficacia para que todos vengan a sentir una cosa o a lo menos no se les haga demasiado pesada [...]" (MHSI: Monumenta Brasiliae IV,1960, p. 330, grifos meus). 
Pax X.

Em esta darei brevemente conta a V. P. do bom sucesso $\left(\mathrm{N}\right.$. Sro ${ }^{\circ}$ nos há dado assim na viagem como depois que estamos nestas partes do Brasil. Partimos de Lisboa a 5 de março de 83 os padres Ro de Freitas, Fernão Cardim e o irmão Barnabé Tello e eu: até chegar a esta Baya, glória ao Senhor, procuramos acudir a gente dela [...] de que se seguiu em todas muita edificação, especialmente em el Sor ${ }^{\circ}$ Governador, que sempre nos trata com amor e benevolência. Aos 9 de maio entramos nesta Baya, que para todos os nossos foi grande consolo, verdade é que foi algo aguardado, porque o Pe. $\mathrm{R}^{\circ}$ de Freitas e eu vínhamos muito enfermos [...]. (ARSI, Lusitania Epistolae - Lus. 68, fl. 337)

Na mesma carta, Gouveia destacava que, logo ao chegar, já começava a colocar tudo em ordem, sobretudo observando e apaziguando os imperfeitos. Repare-se nos termos. Penso que eles estavam em perfeita sintonia com a pedagogia da vigilância, aqui representada pelo "que pede nosso Instituto":

Tendo começada a Visita deste Colégio, e o que em geral posso dizer a V.P. é que ainda que haja alguns necessitados em Espírito e imperfeitos, todavia não me parece que está tão falho na disciplina religiosa e guarda das regras [...] e também de sua parte há alguns apaixonados [...], o que há causado não pequena dissensão e desgostos em muitos. Procuro apaziguá-los no melhor que posso, trazendo-os à união e conformidade que pede nosso Instituto, e parece que se vê alguma melhoria nisto. (idem, ibidem)

Gouveia começava a colocar em prática as ordens de Aquaviva, expressando seu entendimento de que Anchieta já não podia continuar como provincial e de como o reitor do Colégio da Bahia, Gregório Serrão, ocupava-se demasiadamente com as aldeias dos indios e negócios temporais. Em minha análise, esse é um dado interessante para pensar o lugar do jesuíta na sociedade colonial. Repare-se que, por conta da ocupação nas aldeias dos índios, o reitor não tinha tempo para aplicar-se tanto ao espiritual. Esse era um dilema vivido pelos padres e ao qual era atribuída muita importância. Os que se ocupavam dos índios e de sua administração acabavam descuidando do espiritual. Para Roma, esse era um desvio que tinha consequências desastrosas. Veja-se o excerto e suas asseverações:

Estou aguardando a cada dia pelo Pe. José de Anchieta, que anda visitando às partes do Sul e conforme ao que entendo de seu modo de proceder, parece que há menester sucessor porque tem pouca saúde e anda já mui cansado. O Pe. Gregório Serrão, Reitor deste Colégio, faz seu ofício mediocremente, é amado geralmente da gente de fora e dos de casa. É mui virtuoso e de muita confiança, mas por sua má disposição e mui contínuas ocupações com as aldeias dos índios e negócios temporais, que são muitos neste Colégio, não pode aplicar-se tanto ao espiritual dos irmãos e perfeita guarda das regras e assim por isso como por não ter ministro suficiente, nem prefeito das coisas espirituais [...] parece que não andavam as coisas tanto em ordem: pus por ministro o Pe. Antonio 
Gómez; prefeito das coisas espirituais [...] o Pe. José de Anchieta, deixando o seu ofício [...]. (idem, fls. 337-337v)

O visitador apontava ainda a pouca vontade, por parte de alguns jesuítas, de atuarem nas aldeias com os nativos e de aprenderem a lingua do Brasil. Contudo, buscando recurso na "experiência que há", o visitador defendia a permanência do jesuíta na aldeia, já no período de estudos. A posição de Gouveia a respeito, como se verá adiante, seria claramente contestada por Aquaviva.

E nos estudos e diligência de saber a língua do Brasil, há muita frieza e pouco gosto destas nas Aldeias, e se vão acabando os línguas. Comunicando isto com os Pes., pareceu que seria bom remédio que os noviços, acabados os dois anos de probação, fossem às aldeias, a aprendê-la, antes que comecem outros estudos [...] Porque [...] é mui importante que os que governam esta Província saibam a língua do Brasil. Pareceu-me a fazer que aprendam logo a língua, pela experiência que há, que os que vêm de Portugal poucos são os que de verdade se dão a ela nem a tomam facilmente e os que aqui se criam se primeiro os metem em estudos de casos e a estes têm-se depois por mal empregados nas aldeias, nem se aplicam tão facilmente a saber a língua e para este efeito residem quatro em cada Aldeia, dois Pes. e dois irmãos [...] como V. P. me há encomendado, para que quando saírem de casa vão acompanhados e possam entre ano algumas vezes virem ao Colégio e renovarem-se em Espírito e também para que um Pe. com outro se possa confessar [...]. (idem, fl. 338)

Note-se que o visitador estava preocupado com a questão da aprendizagem da lingua do Brasil. Para Gouveia, saber a língua da terra era essencial para o bom governo da província. Mas penso que, especialmente nesse ponto, aparecia também a questão que chamo de lugar do jesuíta na sociedade colonial. O conflito se dava, sobretudo, no entendimento do que era a principal missão do padre: morar na aldeia ou no colégio? Aprender a língua longe das tentaçôes da aldeia ou ir morar entre os que falavam a língua da terra? Os que se metem em estudos estariam mal empregados nas aldeias? Esse conflito continuou com o passar dos anos e, pelo que analiso, não teve solução fácil.

O trecho reproduzido adiante é relevante por evidenciar as dificuldades apontadas pelo visitador na relação entre os padres e os colonos portugueses. Para mostrar as dificuldades, Gouveia apontava quatro causas e reconhecia a parcela de culpa dos inacianos. A meu ver, quando o visitador assim procedia, deixava clara a sua disposição de mudar as práticas e estabelecer novas regras para a província, sobretudo no que concernia ao poder secular que os padres detinham sobre os índios aldeados.

Uma das coisas que há de mais importância nesta Província e que penso que não poderá tão facilmente remediar, é uma geral aversão e murmuração que os portugueses têm dos nossos, da qual nasce dizer contra nosotros, muitas palavras de escândalo e darem muitas queixas ao rei e ao governador [...] As principais causas desta geral murmuração são: a 1ª: por algumas opiniões que há 
entre os nossos, que parecem demasiadamente escrupulosas e contra o comum governo desta terra, como são acerca dos cativeiros e escravos e do modo que se usa de se ter por força os índios livres em perpétuo serviço, sem pagar-lhes nada ou mui pouco; $2^{\mathrm{a}}$ porque recolhemos em nossas aldeias os índios [...]; $3^{\mathrm{a}}$ porque não se-lhes dão das aldeias todos os índios que pedem para seu serviço, posto que padecem falta em suas fazendas [...]; $4^{\text {a }}$ por algumas terras que nos têm dado, parte das quais pretendem algumas pessoas serem suas [...] Bem que creio que em todas estas coisas, ou ao menos em algumas delas, há havido algum excesso de nossa parte [...]. (idem, fl. 338v)

A fim de colocar tudo em ordem, o visitador toma providências bastante significativas, até mesmo corrigindo alguns procedimentos que não estavam conforme ao que ele pensava. Veja-se, no excerto seguinte, que todos os padres eram cuidadosamente colocados em seus devidos lugares e tudo era quitado de acordo com a vigilância disposta pelas ordens de Aquaviva, que chegaram às mãos de Gouveia antes mesmo de sua partida para a visita, estando ele ainda em Portugal. Vale observar que muitos manifestaram o desejo de voltar para Portugal e que algumas cartas trazidas pelo visitador eram destinadas a Anchieta:

Todo o que V.P. me há encomendado nas cartas que recebi em Portugal tenho executado: ao Pe. Vicente R. dei algumas razões como não convinha tratar de sua mudança para Portugal e parece que está quieto e determinado a acabar sua vida no Brasil; o Pe. Manuel Dias, que havia pedido a V.P. o enviasse a Portugal, está em Ilhéus, parece que já não trata de mudar-se, procurarei consolá-lo e animá-lo em o Sr. Nosso; o Pe. Braz Lourenço que é superior na Capitania do Esp. Sto, tenho lhe enviado recado que venha à Congregação Provincial; procurarei quitar-1he o cargo de superior [...] o Pe. Quirício Caxa acude mais às confissões da portaria, especialmente aos domingos e dias santos e com isto se quita a ofensa que dele havia de não querer confessar senão mulheres; ao Pe. Reitor tenho avisado do que parece faltar em seu ofício, como V. P. me encomenda e o mesmo farei com o Pe. Provincial quando vier, e lhe dar as cartas de V.P. [...]. (idem, fl. 340)

A última questão tratada nessa missiva dizia respeito às festas, assunto sobre o qual o visitador tranquilizava o Geral e dizia que nelas "se há posto moderação". um trecho interessante para ilustrar o controle exercido pela Igreja contrarreformista sobre as manifestações coletivas naquele período. Acompanhe-se o excerto:

Nas festas se há posto moderação, não acho haver tanto excesso nelas [...] porque somente alguns quatro ou cinco dias mais solenes do ano, vinham os índios das aldeias a cantar uma Missa em nossa Igreja, para mais confirmação na fé e devoção destes índios. A V. P. peço humildemente sua bênção e ser mui encomendado em seus santos sacrifícios e orações. Deste Colégio da Bahia de todos os Santos, 25 de julho de 1583. (idem, fls. 340-340v) 
No documento seguinte, de dezembro de 1583, Gouveia escrevia a Aquaviva e relatava um clima mais tranquilo na província. É interessante notar que o visitador, por ser aquele que toma conta da consciência dos jesuítas e ouve suas confissões, também tinha condições de fazer um mapa da situação dos missionários e, a partir daí, poderia colocar tudo em ordem e estabelecer novas práticas. $\mathrm{O}$ visitador começava a carta cobrando notícias de Roma a respeito de sua correspondência:

Depois de nossa chegada a estas partes não recebi letra de V. P. e do que aqui se há sucedido foi escrito por duas vias por agosto passado [...] Arribamos por vezes e fomos tomar as Capitanias dos Ilhéus e Porto Seguro. Visitei ali os padres e irmãos, tomando conta de suas consciências ouvindo suas confissões gerais e o mais que toca aos exercícios exteriores e ministérios com o próximo. Achei-os bem ocupados e quietos e que procedem bem na guarda das regras e fazem muito fruto com os portugueses e índios. (idem, fl. 341)

No fragmento seguinte, da mesma carta, Gouveia era claro ao manifestar sua posição em relação aos que se enviavam ao Brasil. Para ele, era preciso que os enviados para cá tivessem vocação de Brasil e que fossem pessoas de virtude e, de preferência, portugueses. Por ser uma vinha laboriosa e perigosa, a província do Brasil requeria padres e não irmãos, porque os irmãos se distraíam por aqui.

me parece que antes venham menos que mais e que fossem pessoas de virtude [...] muitos que de lá vieram nos anos passados, porque como não têm vocação de Brasil, não aprendem a língua, nem se hão acomodado à terra e cada dia se vão desfalecendo no Espírito [...] Por hora parece que bastaria mandar V. P. quatro pessoas: dois para ler teologia, casos e artes e dois para ler humanidade, e se fossem padres todos, muito mais serviriam, porque os irmãos nesta terra [...] se distraem, perdem o Espírito e não dão tão bom exemplo. E outros quatro para superiores que juntamente fossem pregadores e quatro outros para coadjutores temporais que sejam alguns oficiais: mas todos de rara edificação e, quanto fosse possível, portugueses. (idem, fl. 341v)

No início do ano seguinte, chegou a primeira carta de Aquaviva para Gouveia depois de sua vinda à província do Brasil. O Geral estava preocupado sobretudo com os inacianos que viviam nas capitanias e que estavam diretamente ligados ao trato com os índios.

Cópia de uma de N. P. General Cláudio Aquaviva para o Pe. Visitador Christóvão de Gouveia, de 15 de fevereiro de 84.

[...] Os que vivem nas Capitanias parece que são os que levam maior peso e merecem ser mais consolados e ajudados e que a eles V. Rev. tenha em grande conta de consolá-los e de prover semelhantes lugares de superiores suficientes que possam consolar os domésticos e satisfazer às dúvidas e casos que consulta fizerem. (ARSI, Bras. 2, fl. 55) 
No trecho seguinte, pode-se notar que Gouveia, depois de algum tempo na província do Brasil, ${ }^{8}$ já conhecia melhor a realidade e podia dizer sem rodeios:

O gentio desta Capitania está quase todo gastado (porque os mais são de Guiné). $\mathrm{O}$ ano passado desceram do sertão para as fazendas dos portugueses algumas aldeias [...] mas por alguns [...] mal tratamentos que lhes fizeram, se hão tornado grande parte deles; [...] e vieram aqui os principais deles a pedir-me padres que os batizassem. Fui de aqui sete ou oito léguas a visitar-lhes e ver a gente que é e disposição dela; há me contentado [...] e de seu desejo de ser cristãos e o grande amor que nos mostram, fazendo caminho pelas florestas, vindo a receber-nos dois e três léguas antes de chegarmos. (ARSI, Lus. 68, fl. 403)

Gouveia já demonstrava, contudo, que recaía sobre os índios e a conversão destes o sentido da missão no Brasil. Eram eles quem contentavam o visitador, com suas demonstraçôes de amor e com a acolhida que faziam quando eram por ele visitados.

$\mathrm{Na}$ mesma carta, Gouveia defendia o ajuntamento de todos os índios em uma aldeia grande. Para o visitador, a solução para os problemas que a província enfrentava parecia estar nesse proceder. Observe-se:

Pareceu bem que se ajuntassem em uma aldeia grande e fizessem igreja e fossem ali, algumas vezes, padres a instruí-los nas coisas da fé, sem fazer residência entre eles [...] e capitães que thes dêem algum homem principal que tenha cuidado de seu governo temporal e os defendam das injustiças dos portugueses, para que $[\ldots]$ se conservem [...] Porque nenhuma resistência têm de sua parte às coisas da fé. (idem, ibidem)

Repare-se que Gouveia estabelecia um plano no qual o padre se isentava do governo temporal dos nativos. Tal questão, de fato, incomodava o visitador, como é demonstrado em sua correspondência. E aqui aparecia já uma mudança de postura do visitador: no início da visita, ele defendia a permanência dos padres nas aldeias, mas agora estava se convencendo de que se tratava de um lugar perigoso. Parece- me que Gouveia tinha dificuldade de saber o que fazer com a aldeia: ao mesmo tempo em que pensava que os noviços deveriam lá ficar para aprender a língua da terra, também defendia a ideia de que os padres não morassem entre os índios, mas apenas os visitassem. Ora, como seria possível que os noviços morassem nas aldeias sem padres lá residentes? Parece-me um dilema de difícil solução, conforme mostram as missivas.

Gouveia encerrava as assertivas dessa carta pedindo a Aquaviva que enviasse mestres de latim para a província do Brasil.

E [...] V. P. que pusesse algum remédio oportuno para haver estudantes e fazer-se frutos com eles nos estudos. Para isso, não há outro de nossa parte

8 O excerto foi retirado de uma carta datada de “6 de setembro de 84". Portanto, já fazia mais de um ano que Gouveia estava em terras brasílicas. 
senão enviar V. P. alguns mestres de latim como já tenho escrito, e da parte deles se oferecia bom meio haver seminários onde os homens principais que estão pelos engenhos e fazendas, enviassem seus filhos [...] Deste Colégio de Pernambuco, a 6 de setembro de 84. Cristóvão de Gouveia. (idem, ibidem)

Dois meses depois, em $1^{\circ}$ de novembro de 1584 (idem, fl. 408v), o visitador se referia a padre Quirício Caxa, que andava descontente e pouco quieto.

O Pe. Quirício Caxa anda mui desgustado e pouco quieto nesta Província. Até agora não vejo outra causa senão não haver-lhe posto em algum cargo, segundo que por vezes o há significado [...] desejado ajudar-me em semelhantes coisas de suas boas partes naturais de juízo, prudência, bom púlpito e letras, com que tem muita autoridade com os de fora [...]. (idem, fl. 407v)

$\mathrm{Na}$ mesma carta, Gouveia tratava da questão do despovoamento de algumas capitanias, como as de Porto Seguro e Ilhéus. O visitador encontrava dificuldades para prover de gente tais capitanias, as quais podiam ser abandonadas pelos inacianos. Na visão do jesuíta, as capitanias em questão exigiam gente de provada virtude. É interessante notar, uma vez mais, o lugar de destaque ocupado pelas aldeias nas assertivas do visitador.

Como nos anos passados havia muito que fazer nas Capitanias desta Província por ser muitos os índios e portugueses, hão-se tomado aqui algumas residências que agora desejam os padres deixar, máxime as de Porto Seguro e Ilhéus e também [...] em S. Vicente, por haver mui pouco que fazer nelas com os índios e os portugueses que nelas vivem são já mais poucos, e vão despovoando por ser as terras já mui fracas e estéreis e são gente de tal maneira [...] que gostam pouco dos nossos e pouco se aproveitam de nossos ministérios. Além disto é mui dificultoso enviar-se para todas estas residências gente [...] em provada virtude, boas forças e vontade, que possam e queiram estar nelas e assim os Colégios estão sempre em falta destes bons obreiros [...] também o muito que os Colégios gastam com estas residências e o muito que custa aos provinciais visitar estas duas $[\ldots]$ e sem estas, facilmente se visitaria toda a Província a cada dois anos [...]. (idem, fl.408)

Logo em seguida, Gouveia propunha o modum missionis, pelo qual os padres não necessitariam viver nas aldeias, mas as visitariam de vez em quando. Essa prática recebeu o apoio de Aquaviva, mas não contava com o apoio dos padres da província do Brasil. Eis a proposta do visitador:

Por estas razões e outras muitas, me parece que assaz estariam estas residências bem providas, e suas necessidades remediadas [...] se cada ano fossem a elas dois padres a visitar-lhes, por "modum missionis", pregando e confessando [...] O mesmo que digo destas Capitanias, se propõe também pelas mesmas causas delas, três aldeias que aqui temos, em cada qual havendo destas quatro dos nossos, são 12 pessoas, as quais não podem ser todos padres, nem irmãos coadjutores por não havê-los. (idem, fl. 408) 
Por fim, Gouveia tratava da questão dos estudos no Colégio da Bahia e relatava uma situação de ociosidade e pouco rendimento entre os estudantes, que leram somente oito artigos de Tomás de Aquino em um ano. Confira-se que a exceção dizia respeito apenas aos que se dedicavam ao estudo da lingua:

Os estudantes perdem muito de seus estudos e estão lá em ócio, mal ocupados, exceto dois ou três que aprendem a língua, pelo que também parecia que algumas aldeias poderiam visitar-se [...] O especulativo da teologia vai tão "despacio" neste Colégio $[. .$.$] porque me hão dito que em um ano só oito artigos de S. Thomas$ há lido o Pe. Quirício, e por ser isto em muito detrimento de nossos estudantes e do fim que se pretende nas constituições [...] com o Pe. Leonardo Armínio que havera de ser o leitor em lugar do Pe. Quirício, que já é cansado, que dentro de quatro anos [...] leia-se o mais principal do especulativo, deixando a moral para o lente de casos e desta maneira deixarão mais breves os ditados, para que não se cansem os estudantes, nem gastem todo o tempo em escrever sem saber nada [...] Deste Colégio da Bahia, $1^{\circ}$ de novembro de 1584. (idem, fls. 408-408v)

$\mathrm{Na}$ carta que se segue, também de $1^{\circ}$ de novembro de 1584 , Gouveia insistia em falar de José de Anchieta e, no seu modo de entender, de sua insuficiência para o cargo de provincial, por já não ter saúde para tanto. Para o visitador, Anchieta deveria ficar sem ocupação alguma. Porém, penso que a questão central aqui não era a saúde de Anchieta, mas o fato de que ele era um representante da via amorosa ${ }^{9}$ no trato com os demais padres da província. Por isso, desde o início da visita, Gouveia tratava de construir uma argumentação capaz de destituí-lo do cargo de provincial e, ainda mais, de qualquer cargo dentro da província. Essa, parece-me, era também a vontade de Aquaviva. Repare-se nas assertivas do visitador:

Acerca do Pe. José de Anchieta, depois de minha chegada a esta Província, nunca há tido saúde para fazer seu ofício e há me ajudado mui pouco e não está já para nada, nem para poder ter uma consulta com ele. Pelo que me parece que depois de se the dar sucessor, devia deixar sem ocupação alguma [...] determino levar-lhe ao Rio de Janeiro para deixar em aquelas partes [...]. (idem, fl. 410)

$\mathrm{Na}$ mesma carta, Gouveia relatava que havia sido posto um aviso para que os estudantes pudessem ir à aldeia para aprender a língua. De acordo com tal aviso, não se poderia fazê-lo no colégio. Interessante observar que o aviso fora feito com o parecer dos padres antigos. Essa questão é importante para se pensar na postura da província em relação à aldeia. Gouveia ficava no meio do embate: de um lado, Aquaviva, contrário à ida dos noviços para a aldeia; e de outro lado os padres antigos, que certamente enxergavam nesse caminho uma condição para que a empresa missionária com os índios não desfalecesse. Gouveia reproduziu a vontade dos padres da província, para os quais a questão do aprendizado da língua da terra era

9 A chamada via amorosa refere-se à postura condescendente de alguns jesuítas, relativamente à conduta não ortodoxa de outros colegas padres que atuavam na província do Brasil. Para uma discussão mais aprofunada sobre o assunto, ver Faria (2009). 
tão importante que até mesmo queriam que esta fosse a condição para se promover o estudante à outra faculdade. Acompanhem-se as palavras do visitador:

E na ordem que V.P. há dado na Província do México acerca de se aprender a língua dos naturais, o que se oferece é que já tinha posto aqui um aviso nos $\mathrm{Co}^{-}$ légios acerca disto, com parecer dos padres antigos, por ver a muita necessidade que havia de pessoas que soubessem a língua e o grande descuido em aprendê-la. Tal aviso é o seguinte: "Os irmãos estudantes acabados os dois anos de sua probación vão às aldeias a aprender a língua os que não a souberem. E dando-se a ela com diligência e ninguém passe [...] a outra faculdade sem que primeiro a saiba mediocremente; mas com alguns, por particulares causas, poderá o Pe. Provincial dispensar 'auditus suis consultoribus"'. (idem, ibidem)

Ainda na mesma carta, porém, Gouveia parecia estar desanimado quanto ao aviso e pedia ao Geral que não apertasse tanto a mão sobre a obrigação de aprender a língua da terra, pois muitos não tinham sequer vontade de aprendê-la. Esse trecho é interessante porque demonstra uma incompatibilidade entre os avisos decretados pelo visitador, com a aprovação dos padres antigos, e a postura dos que se destinavam à carreira eclesiástica e que certamente não tinham interesse em trabalhar com os índios. Contudo, Gouveia amenizava a questão e afirmava que aqueles que não se interessavam em aprender a língua não ficariam desocupados na província. Mesmo assim, ele insistia em que os aspirantes ao sacerdócio estivessem um tempo nas aldeias como companheiros dos padres, a fim de compreenderem a língua.

E com ser este aviso não tão apertado não faltam alguns que lhes pareça áspero e dificultoso na execução, posto que me parece, parecendo bem a V. P., que por hora, não se apertasse tanto a mão, em que nenhum possa ser sacerdote sem saber a língua dos naturais: porque há alguns que nem idade, nem habilidade, nem vontade têm para isto, e [...] podem servir em outros ministérios, como de procuradores, confessores e superiores, como há muitos nesta Província, que estão bem ocupados sem saber a língua. Além disto, em nenhuma maneira pode aqui enquadrar que se aprenda a língua dentro dos Colégios, porque há se experimentado, e depois de muitos anos haver-se trabalhado muito nisto [...] e o remédio mais próprio e de que sempre se há usado é estar nas aldeias dois ou três anos por companheiros dos padres que delas têm cuidado e com isso virem a saber a língua $[. .$.$] . (idem, ibidem)$

No fragmento seguinte, o visitador deixava claro ao Geral que era quase impossível satisfazer na província do Brasil aos desejos de Roma em relação à organização dos estudos. As causas para tanto vinham descritas na sequência:

Acerca da academia de exercícios de humanidade que V. P. escreve, se haja dentro de casa para fazer mestres, é coisa muito para desejar e logo que cheguei a esta Província [...] o procurei. Mas em nenhuma via é podido [...], porque quatro ou cinco estudantes humanistas que havia, estavam tão apartados nos ofícios, aldeias e Capitanias que com dificuldade se há de ajuntar neste Colégio, 
para que pudessem continuar seus estudos e assim possam sair tais que sejam mestres nas primeiras classes, por que os mestres que têm sabem pouco e a terra é tão desleixada e contrária aos estudos [...] pelo que parece que sempre será remédio vir do Reino alguns peritos na língua latina, para ler aqui humanidade, máxime nas primeiras classes. (idem, ibidem)

Havia ainda outras dificuldades nos estudos, que eram descritas sem rodeios por Gouveia. Muitos estudantes não se dedicavam inteiramente aos estudos por conta das demais ocupações e, dessa forma, não sabiam o necessário para se tornarem padres. Avalio que esses excertos são importantes para se pensar a atividade $e d u c a-$ cional dos jesuítas na colônia. Eles demonstram claramente que os decretos oficiais e a organização dos estudos presentes, por exemplo, no Ratio studiorum, eram, em grande parte, inaplicáveis por aqui, sobretudo em virtude das muitas ocupações que as terras brasílicas obrigavam aos padres. Havia, a meu ver, um descuido em relação à organização estrita dos estudos no período porque a realidade da colônia apresentava aos inacianos outras necessidades. Vejo também, aqui, uma das consequências do envolvimento dos padres em questões seculares. Ou seja, é por conta desse fato que os padres não se dedicavam com afinco ao empreendimento educacional e por isso havia desgosto no estudo. Confira-se:

Muito é desejado e procurado que os estudantes tenham seus estudos quietos, sem interrupções, porque há muitos de idade de trinta e mais anos, que hão começado muitas vezes a gramática e não hão terminado com ele por ocupações, e tem já tomado tanto desgosto no estudo que com muita dificuldade poderão aproveitar e saber o que é necessário para ordenar-se. Sendo admitidos por estudantes e procedido com edificação, não se podem aplicar ao estudo de coadjutores e assim tenho muita pena por não poder consolá-los, como eles pedem e desejam, fazendo-os sacerdotes, com tão pouca suficiência [...] Posto que, por falta de coadjutores, são forçados os superiores ajudar-se muito dos estudantes [...]. (idem, fl. 411)

No período da visita de Gouveia, era evidente também uma questão que incomodava alguns inacianos: os naturais da terra eram excluídos do noviciado, sobretudo por serem considerados inconstantes (Leite, 1938-1949).

Em 1584, resolveu o visitador sobre-estar na admissão de noviços [...] Por este tempo, começaram a vir ordens apertadas de Roma para se não receberem naturais da terra, pela inconstância de que davam mostras; e sucedeu que, chegando, em 1592, à Baía, sete noviços do Rio de Janeiro e do Espírito Santo, só acharam dois no noviciado. (idem, fl. 398)

O visitador, no entanto, encarou o problema e pareceu cada vez mais convencido a aceitar o que se praticava na colônia - e, portanto, cada vez mais distante daquilo que era desejado por Roma. Dessa maneira, em alguns assuntos estava de acordo com o que queria o centro da Companhia - por exemplo, sobre as ocupaçóes temporais dos padres -, e em outros deixava clara a impossibilidade de se aplicarem aqui as ordens do Geral - por exemplo, impedir que os nascidos no Brasil seguissem 
carreira eclesiástica. No fragmento transcrito adiante, Gouveia defendia os nascidos no Brasil e dizia que eram eles que suportavam o peso da colônia e que tinham muita graça, eficácia e autoridade com os indios.

Os sujeitos nascidos no Brasil, que agora há, os mais se receberam antes do ano de 79, em que o Pe. Everardo, de boa memória, ordenou que não se recebessem. E pelo que tenho aqui visto, posso afirmar a V.P. que eles são os que levam a maior parte do peso e trabalho na conversão, doutrina e aumento da nossa cristandade. Que se eles não fossem, mal se poderia conseguir o fim que aqui se pretende, porque como a língua brasílica é a eles quase natural, têm muita graça, eficácia e autoridade com os índios para fazer-lhes práticas das coisas da fé e os persuadem tudo o que é menester para tê-los quietos e contentes e como são nascidos aqui, sofrem mais facilmente os trabalhos contínuos e poucas comodidades que aqui há para viver $[. .$.$] e ainda que estes portugueses naturais daqui não sejam tanto$ para reger Colégios, especialmente em cargos de reitores e provinciais, não tenho por coisa de menos peso e importância isto de atender à conversão e doutrina dos índios; com vê-los fazer de contínuo e com muita edificação e ainda que alguns destes tenham caído, também nos outros se hão caído grandes faltas e com menos ocasiões. Pelo que tenho já escrito a V. P. que parecia aqui não se deveria apertar tanto a mão nisto [...] e assim me hão pedido todos os padres de mais inteligência e experiência desta Província, que isto se apresentasse a V. P. Deste Colégio da Bahia, $1^{\circ}$ de novembro de 84. (idem, fls. 411-411v)

Alguns anos mais tarde, contudo, em 13 de fevereiro de 1596, o padre-geral Cláudio Aquaviva, em carta escrita ao provincial Pero Rodrigues, reforçava a proibição: "que não se recebam nessa província os naturais do Brasil [...] Porque a experiência tem mostrado a cada dia que não nos convém tal gênero de gente" (ARSI, Bras. 2, fl. 90, grifos meus). ${ }^{10}$

Em 1598, no entanto, a Congregação Provincial tornou a insistir sobre a admissão na carreira eclesiástica na província do Brasil, de portugueses, filhos de portugueses e mamelucos, que só atingissem o parentesco com os índios no quarto grau. O Geral mostrou-se, dessa vez, menos inflexível, permitindo a entrada de portugueses e filhos de portugueses com as disposições devidas. Mas acentuava: "é preciso que tenham realmente dotes e sejam longamente provados" (Aquaviva apud Leite, 1938-1949, p. 435-436). Manteve, contudo, a proibição a respeito dos

10 No início da empresa missionária, eram admitidos os naturais da terra. Tem-se como exemplos Pero Correia, Mateus Nogueira, Antonio Rodrigues (Leite, 1938-1949, p. 434). A meu ver, esse é um deslocamento e uma mudança de prática bastante ilustrativos para pensar a atividade jesuítica no período, porque, como disse Aquaviva, "a experiência tem mostrado" a inconveniência de admitir os naturais da terra na Companhia. Nesse sentido, é interessante interrogar: o que provocou tal mudança? Por que Nóbrega não via dificuldade em admitir os naturais da terra no início da empresa missionária? Recorde-se que Mateus Nogueira, natural da terra, era personagem que ocupava um lugar central no Diálogo sobre a conversão do gentio, de Nóbrega. A respeito do Diálogo, conferir Faria (2005, p. 122-128). 
mamelucos, qualquer que fosse o grau de parentesco que atingissem com os índios. Uma "longa experiência", dizia ele, tinha mostrado que os tais, em "ambas as Índias, não são de forma alguma idôneos para a Companhia" (idem, ibidem).

Repare-se que a província do Brasil não abria mão de suas convicções e insistia em convencer o Geral a aceitar os nascidos no Brasil. Este persistia, contudo, na exclusão dos índios e de seus parentes da carreira eclesiástica.

Em uma das raras vezes em que explicitou preocupação com os colonos portugueses, ${ }^{11} \mathrm{o}$ visitador escreveu a Aquaviva, apresentando a necessidade de pensar na educação dos filhos dos colonos. $\mathrm{O}$ visitador então propôs a construção de casas para esse fim:

Quanto ao modo de seminários que aqui se deseja instituir [...] parece-nos que em Pernambuco, Bahia e Rio de Janeiro houvesse alguma casa em que se pudessem recolher os meninos filhos de portugueses e que estivessem imediatos a alguma pessoa, ou clérigo secular, sendo de quando em quando visitados e instruídos pelos da Companhia e que os padres tivessem o necessário para sua sustentação. As razões que para isto [...] são propriamente porque, nestas partes, a maioria dos moradores com sua família reside fora em suas fazendas e engenhos e poucas vezes entre anos vêm à cidade [...] têm seus filhos nas fazendas, aonde têm muitas ocasiões de perderem-se e mui poucas doutrinas e exemplo de virtude, os quais se tivessem nas cidades casa aonde pudessem os filhos e pessoas que deles tivessem cuidado, todos folgariam muito mandá-los ao estudo e por esta causa há mui poucos estudantes nestas partes. Existem muitas vilas aonde temos residências e não escolas. Desejam muitos de poder ter comodidade de mandar seus filhos a aprender em nossas escolas e por falta de casa e pessoas que deles tenha cuidado, o deixam de fazer e esta é a causa de haver aqui tanta falta de clérigos [...]. (ARSI, Lus. 69, fls. 131-131v)

O visitador, portanto, preocupou-se também com a organização do modo de seminário, a fim de retirar os filhos dos portugueses das fazendas, porque ali eles tinham muitas ocasióes de perderem-se. Era mais uma tentativa de organizar o corpo disperso.

\section{SOBRE A LEGISLAÇÃO PRODUZIDA PELA VISITA: VIGILÂNCIA E DISCIPLINA}

Padre Manuel Viegas, residente na capitania de São Vicente, escreveu uma carta ao padre-geral Aquaviva sobre os frutos da visita de Gouveia. Essa carta foi escrita logo após o término da visita, no dia 21 de março de 1585 (idem, fl. 63v). Aqui é importante perceber as observações do jesuíta ao falar do visitador e das providências tomadas após sua visitação, principalmente no que dizia respeito ao aprendizado da língua da terra. Note-se que aparecia mais uma vez o desinteresse do jesuíta pelas atividades desenvolvidas com os nativos em suas aldeias:

11 Ver carta “Da Bahia, a 16 de agosto de 1585” (ARSI, Lus. 69, fl. 131v). 
Pax Christi.

Padre mio em Xto.

[...] Mui bem foi recebido o padre visitador nesta Capitania [...] com cuja Visita e bom modo de tratar e bom modo de falar com todos se alegraram e consolaram todos [...] Grande é o zelo que tem da conversão deste gentio do Brasil e assim manda que todos que são para isso aprendam e saibam a língua da terra e nenhum (conforme ao que de V. P. mandou) manda ordenar de ordens sacras ainda que seja muito para isso, sem que primeiro saiba e aprenda a língua da terra. E assim foi bem ordenado de V. P. porque sabe V. P. que mui poucos a queriam aprender e saber e dar-se a ela: e todos eram dar-se às letras e serem pregadores dos portugueses e subir ao púlpito a pregar aos brancos e não se recordavam desta pobre gente de lhe pregar em sua língua. (idem, fls. 62-62v)

$\mathrm{Na}$ mesma carta, Viegas esclarecia o motivo pelo qual era tão necessário saber a língua dos nativos. Veja-se que o jesuíta depreciava a gente do Brasil, para a qual poucas letras bastavam:

As letras em toda parte são mui necessárias e mais em umas partes que em outras: no Japão são mui necessárias porque é gente de melhor saber e sutil engenho e é necessário saber-lhe responder a suas sutis perguntas. Mas por aqui, para esta gente do Brasil, poucas letras bastam e quem nesta terra sabe a língua dela é aqui teólogo. E muitos padres que vêm de lá teólogos nos dizem que se pudessem ser, que dariam a metade de sua teologia pela língua e eu digo a V.P. que não darei minha língua por toda sua teologia [...]. (idem, fl. 62v)

Ao final de sua carta, porém, Viegas parecia estar disposto a convencer Roma de que os nativos eram boa gente. Para tanto, falava de uma nova tribo, os Maromeri, gente que não comia gente. Confira-se:

É esta gente mui boa, amigável e tem boa inclinação e folga muito de saber e aprender as coisas de nossa Santa fé. Esta gente maromeri não come gente, não tem cada um mais que uma mulher, pelo que com eles se pode fazer muito. E saiba V.P. que já em suas aldeias não sendo cristãs, tem já cruzes [...] alevantadas. O Pe. Visitador determina agora, com a ajuda de nosso Senhor, a mandar-me falar-lhes. E já tem conhecimento e notícia dos padres, a quem eles chamam axé [...]. (idem, fl. 63)

É fundamental reafirmar, no entanto, que a missão do visitador era, sobretudo, a de apertar o cerco em torno das questões internas da Companhia de Jesus no Brasil e dissipar o perigo de cair nas tentações que o Novo Mundo oferecia ao padre. Assim, em 1584, o padre visitador despediu seis irmãos da Companhia: quatro escolásticos e dois coadjutores, e dava as razões para a saída: "três por indisciplina, três por questões de sexto mandamento; ${ }^{12}$ destes últimos, um era mameluco,

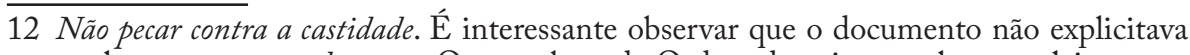
qual era o sexto mandamento. Os membros da Ordem deveriam conhecer as leis que os 
outro flamengo, do terceiro não se diz a nacionalidade”. Leite (1938-1949, p. 451) analisou os documentos relativos à despedida de alguns inacianos e destacou que

A grande ocasião foi o trato com os índios. Numa lista, dos que tinham saído antes de 1603, a maioria tem a designação de línguas, isto é, os que tratavam imediatamente com os índios. São quási todos irmãos, e grande parte da terra.

Veja-se que a causa da despedida estava no trato com os índios e na admissão de naturais da terra no interior da Companhia. O trato com os índios era visto como prejudicial à preservação da vocação jesuítica. Por isso muitos resistiam à ideia de ir morar na aldeia, a começar pelo Geral em Roma. Porém, quero destacar, em especial, que a dispensa de alguns irmãos por parte do visitador era significativa. Esse não era um procedimento simples, mas de controle e de tentativa de preservar o bom odor da Ordem diante da sociedade colonial.

Era preciso, pois, regulamentar todos esses processos e torná-los claros. As ordenações do visitador vigoraram durante todo o século XVII e somente começaram a ser revistas no início do século seguinte. Até sua visita, não se conheciam no Brasil muitas normas da Companhia, chamadas de instituto, como comprova carta enviada por Aquaviva a Gouveia:

Cópia de uma de N. P. Geral Cláudio Aquaviva para o Pe. Christóvão de Gouveia, Visitador, de 11 de abril de 83.

Porque o último privilégio que têm os Mestres de Noviços para mostrar aos demais que se foram para ler aos que estão nas Casas de probacion há parecido imprimir de alguns exemplares com alegações à margem para que os que não têm tanta notícia do Instituto, possam de outros muito lugares que hajam as Constituições e [...] alguns principais que nela se alegrem [...]. (ARSI, Bras. 2, fl. 54)

É também nesse sentido, conforme saliento, que pela visita de Gouveia é que se pôs em cena a pedagogia da vigilância jesuítica, amparada pelos decretos contrarreformistas e pelos mandamentos daquele que quis colocar tudo em ordem: padre Cláudio Aquaviva.

Assim, ao final de sua visita, Gouveia mostrou a que veio. A visita não era somente para conhecer a terra. Era, acima de tudo, para colocar tudo em ordem. Em seu Memorial dessa visita, por exemplo, Gouveia insistia em regulamentar algumas questões sobre a prática dos missionários na província do Brasil. Para o visitador, as questões de casamento entre índios e escravos e da excomunhão aos colonos que roubavam índios exigiam regulamentação. Confira-se:

Memorial do Pe. Visitador.

Pede a resposta sobre os casamentos dos índios e escravos de Guiné [...] Que se haja excomunhão contra os que furtão [...] índio ou índia das aldeias que os padres têm a cargo. (ARSI, Lus. 68, fl. 418)

policiavam e supunha-se que todos já sabiam das punições advindas do não cumprimento delas. 
Castelnau-L'Estoile (2006) notou que, se as condições de exercício do apostolado não eram fáceis no Brasil, as dificuldades dos missionários não eram simplesmente externas, e a vinda de Gouveia foi diretamente provocada por problemas internos à província, tais como a insuficiência de superiores e o conflito em torno da posse de escravos. $\mathrm{Na}$ correspondência administrativa que o visitador enviou ao Geral, percebem-se ecos diretos desses problemas internos. O visitador tranquilizava o centro quanto aos superiores da província, diluía o conflito sobre a escravidão e enviava de volta à Europa os padres muito intransigentes. $\mathrm{O}$ visitador retomava a questão das aldeias frequentemente nas cartas, de forma mais negativa, contrastando fortemente com o relato suavizado de Cardim. Em sua primeira carta, de 25 de julho de 1583, Gouveia se limitava a evocar o desprazer dos jesuítas por estarem nas aldeias ("pouco gosto destar en las aldeas"); um pouco adiante ele observava que aqueles que estudaram "consideram-se mal empregados nas aldeias"13 (Gouveia apud Castelnau-L'Estoile, 2006, p. 127-128).

Ao final de sua visita, o trabalho de Gouveia consistia em insuflar o espírito das constituiçôes na aldeia missionária, compondo um regimento das aldeias. $\mathrm{O}$ regimento era dividido em cinco grandes seções. Em primeiro lugar, ele previa regras para o conjunto dos jesuítas da província: vinte e dois parágrafos "Para lo general de la Província", concernindo, por exemplo, aos horários, à formação, à correspondência. Depois o regimento enfocava regras particulares, conforme os diferentes lugares onde se podiam encontrar os jesuítas da província: o colégio, as capitanias, a aldeia e as missões. Essa mistura entre os termos jesuíticos (colégios e missões) e os termos especificamente brasileiros (capitania e aldeia) é emblemática do procedimento que presidiu à elaboração desse regimento: adaptar o espírito da companhia (idem, p. 129-130).

O papel da visita de Gouveia era também o de unificar as práticas espirituais. Para ajudar o jesuíta a alcançar sua salvação, o regimento deveria ajudá-lo a não cair em pecado. Era preciso, portanto, limitar as oportunidades, especialmente evitando-se a solidão de qualquer jesuíta (idem, p. 138).

Desenhava-se então, pelo regimento, uma espécie de clausura imaginária, constituída pelo olhar do companheiro sempre presente. Observe-se:

Não se mande de ordinário ninguém fora da casa sem companheiro, sem licença especial do padre provincial, nem por fora se apartem um do outro por distância em

13 Discordo de alguns pontos apresentados pela autora. Penso que Gouveia não conseguiu tranquilizar o centro da Ordem em relação aos superiores, até porque ele próprio não estava satisfeito com Anchieta, por exemplo. Também penso que o visitador não tinha uma visão negativa das aldeias. Pelo contrário, foi nas aldeias que ele passou a maior parte do tempo e era defensor da ideia de que os noviços deveriam morar um tempo nelas. Aliás, nas cartas com as quais trabalhei, é possível ver que Gouveia não se limitava a evocar o desprazer dos jesuítas pelas aldeias, mas demonstrava que lá era que se constituía a identidade da missão jesuítica na província do Brasil. O que Gouveia fez, isso sim, foi regulamentar tal espaço, não por vê-lo de forma negativa, e sim por se interessar por ele. Penso que, se havia uma visão negativa das aldeias, esta não era de Gouveia, mas do padre-geral e de alguns padres que não queriam absolutamente residir naquele espaço. 
que não se possam ver um ao outro, a não ser por uma grande necessidade, e quando retornarem à casa que prestem contas disso ao superior. ("Para lo general de la Província”, §9, ARSI, Bras. 2, fl. 141, grifos meus)

O regimento aparecia como elemento fundamental no equilibrio da província, mas sobretudo como um mecanismo de controle, vigilância e ordenamento. Veja-se, pelo excerto seguinte, que o visitador apertava o cerco em relação à prática jesuítica de ir buscar índios no sertão:

Não irão os nossos ao sertão a buscar índios gentios nem darão seu parecer para lhes ir fazer guerra sem especial licença do padre Provincial, o que tal não dará senão em algum caso raro e de muito serviço de N. Senhor. (idem, ibidem)

Diferentemente do período em que padre Manuel da Nóbrega praticava a via amorosa, quando os meninos índios eram intérpretes nas confissões, agora somente os coadjutores poderiam sê-lo:

Coadjutores temporais se esforcem quanto for possível estarem de ordinário nas aldeias e aprender a língua de propósito e serem intérpretes nas confissões. (idem, ibidem)

O fragmento reproduzido a seguir é muito interessante porque demonstra o quanto o jesuíta desejava manter o controle sobre a vida dos índios que viviam nas aldeias e sobre eles aplicar a pedagogia da vigilância, aqui expressa pelas visitas constantes aos nativos e pela informação minuciosa sobre seus costumes e práticas. É fundamental também observar o acréscimo feito por Aquaviva em Roma:

Os superiores dos Colégios ou Capitanias onde houver aldeias devem ir pelo menos uma vez por ano visitá-las, e que se informem se há alguns pagãos, escandalosos, feiticeiros ou amancebados e se se confessaram todos na quaresma, se vêm à Missa aos domingos e festas, e às doutrinas rotineiras, e se há algum por casar tendo idade para isso, ou se estão fora da aldeia sem licença, e deem-lhes remédio conveniente a suas almas de tal maneira que se veja e se entenda que o fazem por caridade como padres e não juridicamente, pois seria usurpar o cargo do bispo e ofendê-lo, ${ }^{14} \mathrm{e}$ façam cumprir inteiramente os avisos que estão dados para as aldeias e procurem que na medida do possível sejam providos de todas as ajudas corporais e espirituais os padres e irmãos que nelas residam. ("Para lo general de la Província”, §13, ARSI, Bras. 2, fl. 141, grifos do original)

De acordo com Castelnau-L'Estoile (2006), uma vez que a aldeia representava um perigo de diluição da identidade jesuíta, o regimento previa a reafirmação dos laços entre o missionário e a instituição. Assim, o regimento de Gouveia explicava qual deveria ser a organização da aldeia como espaço jesuíta; dessa forma, ele dava

14 Nos excertos do regimento, "tudo o que está riscado por baixo foi acrescentado em Roma pelo N. P. Geral” (ARSI, Bras. 2, fl. 148). 
ao missionário os meios de garantir sua salvação, naquelas condições difíceis, ou mesmo adversas. A aldeia era considerada, portanto, um lugar de tentações (idem, p. 135-137).

O regimento de Gouveia, portanto, também escancarava uma questão: a aldeia era um lugar perigoso! Esse mote aparecia ao longo de todo o documento. Isolados entre as populações que os jesuítas consideravam caracterizadas pelo pecado, os missionários corriam o risco de perder ali sua identidade jesuíta. Para quebrar o isolamento da aldeia, o regimento insistia sobre os laços que deviam unir o restante da instituição aos missionários isolados. Tais laços eram materializados pela visita anual obrigatória do superior da residência ou do colégio do qual dependia a aldeia.

A questão do uso de intérpretes voltava a aparecer e Aquaviva fez novamente um acréscimo ao texto. Havia, ainda, a proibição de atender os índios que estivessem desnudos, o que explicitava o controle sobre o corpo.

Não se usem intérpretes, senão com necessidade e quando houver, sejam pessoas de confiança, dos quais não se apartem os confessores, quando ouvem semelhantes confissões, mas estejam presentes e o intérprete refira-se às palavras como o penitente as for dizendo para ajudar-lhe melhor e perguntar-lhe o que fora menester. Nem se confessem homens nem mulheres totalmente desnudos, ${ }^{15}$ podendo haver algum modo para virem decentemente vestidos. ("Para lo general de la Província”, §13, ARSI, Bras. 2, fl. 142, grifos do original)

Os trechos transcritos adiante dizem respeito aos colégios. No primeiro aparece a exigência de saber latim para ser admitido como estudante.

A ninguém se receba por estudantes sem saber bem o latim, ou pelo menos, ter habilidade e idade para antes de ser de 25 anos aprendê-lo, ou antes dos 30 se soubesse a língua, ou outras raras partes. E para isso se lhes dê o tempo necessário. (“Para los Colegios", § 12, ARSI, Bras. 2, fl. 143, grifos do original)

O parágrafo seguinte é fundamental, não somente pelo que está prescrito, mas porque no original está todo rabiscado, o que, contudo, não o tornou ilegível. A razão é clara: Aquaviva era contrário ao que Gouveia prescreveu nele. Ele nunca se mostrou favorável à residência do noviço na aldeia, como revelavam outras determinações do Geral. Veja-se o texto que foi rabiscado:

15 A partir de então, tal questão me parece normatizada. Contudo, ainda gerava dúvidas, como mostrou a pergunta apresentada a Aquaviva pelo provincial Marçal Belliarte, em 1592: "Si es bastante causa para no obligar a uno que deprenda la língua entre los índios, dizir que le es danosa la vista de mugeres desnudas" (ARSI, Congregationes Provinciarum - CP. 46, fl. 155v). Ao que Aquaviva respondeu, em janeiro de 1594: "A caridade e o ofício do superior pedem que em tais casos não ponha o súdito em perigo. Porém, quando se suspeitasse que aquele temor do súdito nasce da imaginação, ou apreensão, ocupe ao tal em alguma coisa na qual se entende que tenha repugnância e por outra parte poderá por meio do confessor procurar sanar aquela dificuldade" (idem, fl. 316v). A via proposta pelo Geral é a do sacrifício e da penitência. 
Os noviços podem cumprir o mês de peregrinação [...] indo com algum padre pelas fazendas em missão. E os estudantes dentro de um ano aprendam a doutrina na lingua e antes de acabarem a probação irão residir nas aldeias, onde ouvirão um mês, para poder ensinar. (idem, ibidem, grifos meus)

O fragmento seguinte trata da questão do governo secular por parte do superior. Essa era uma das questões cruciais para o jesuíta naquele período e constituía-se no ponto de maior discordância entre os membros da Companhia da província do Brasil e a direção da Ordem em Roma. O excerto mostra também que o problema do governo temporal não estava restrito aos padres que viviam nas aldeias. No colégio, tal desvio de conduta também era possível.

Meter-se o superior muito no governo particular das coisas temporais é grande impedimento para entenderem em outras de mais importância. Pelo que deve comumente executar as coisas particulares pelo ministro ou mestre de noviços, se a eles pertencerem, e não se meter imediatamente nelas senão com necessidade. (idem, fl. 144)

O parágrafo adiante prescrevia o currículo para o curso de artes. Na parte sublinhada, Aquaviva acrescentava que em Roma já se tinha um esboço do Ratio studiorum e que ele deveria ser enviado às províncias: ${ }^{16}$

No Colégio da Bahia, depois da lição de casos e da de latim, se vierem dez estudantes de fora pelo menos que saibam bem latim, se poderá começar o curso de artes, o qual se acabará em três anos [...] As disputas do curso que se costumam ter em casa se podem ter na classe todos os dias na última meia hora pela manhã e pela tarde. Haja também uma lição de teologia na qual, enquanto não chegar a ordem dos estudos que de Roma se enviará a todas as Províncias, se guardará este: explicarão as três partes de S. Tomás com tal ordem que em quatro anos se tenham as principais matérias do especulativo: no primeiro ano, a matéria de Beatitudine, Scientia Dei, Voluntate Dei, Predistinatione, Trinitate, Angelis; e no $2^{\circ}$ e $3^{\circ}$ anos: De Voluntatio, Peccatis, Gratia, Fide, Spe et Charitate; no quarto ano: De Incarnatione e as mais que puderem dentro dos quatro anos. As demais matérias de S. Tomás se poderão deixar para o que fizer a lição de casos, na qual somente se lerá Caietano [...], de maneira que dentro de três ou quatro anos se leiam as principais vias morais: De Conctractibus [...], Voto, Juramento, Sacramentis et Censuris [...]. ("Para los Colegios", § 24 e 25, ARSI, Bras. 2, fl. 144, grifos do original)

16 Essa é uma das únicas referências ao Ratio studiorum que encontrei no material referente à província do Brasil, pesquisado no ARSI. Esse dado me parece interessante, pois, no que se refere à organização dos estudos no início do século XVII, o Ratio não exerceu influência imediata, como foi o caso das constituições jesuíticas de 1556. 
Por fim, o parágrafo seguinte determinava a execução de conclusões públicas, que se davam por meio de disputas: ${ }^{17}$

Cada semana haja conclusões públicas de casos ou teologia e façam os superiores ir sempre nelas alguns teólogos antigos [...] se poderá ter [...] disputas magnas em que se defendam algumas matérias de Artes, Theologia e Casos [...]. (idem, ibidem)

É interessante perceber que, sobretudo após o Concílio de Trento, Tomás de Aquino passou a ser o autor preferido dos jesuítas e foi incorporado como leitura obrigatória nos cursos mantidos nos seus colégios. Esse é um exemplo importante para se pensar no conteúdo da campanha pedagógica contrarreformista. Como foi possível observar, é com base nos textos do referido autor que se determinava a doutrina sobre Deus, os anjos, a alma, o bem e o mal e a predestinação. Lia-se, portanto, o conteúdo da teologia tomista, que a Companhia de Jesus considerava a sua própria. Tal conteúdo garantia certeza em tempos de instabilidade, sobretudo no campo da busca pela via da salvação.

\section{ALGUMAS CONSIDERAÇÕES}

Penso que, pelos apontamentos feitos neste artigo, um dos conceitos importantes para discutir a missão jesuítica na província do Brasil é o de negociação. Nesse sentido, foi possível observar que o visitador, apesar de vir munido de autoridade para aplicar a pedagogia da vigilância, ao se deparar com a realidade da província do Brasil, concluía que era preciso negociar com Roma, principalmente sobre aqueles pontos que percebia serem inaplicáveis por aqui. No entanto, o desejo de colocar tudo em ordem acabou por afetar a prática dos inacianos no período estudado.

Para finalizar, ao que me pareceu, o ensino jesuítico passava por um processo de reorganização e de adaptação às condições da colônia no período. Num tempo de crise no interior da própria Ordem, penso que as ordenações de Aquaviva, ao explicitar a rigidez e a vigilância, tiveram consequências importantes para a província do Brasil: por exemplo, ao não admitir os naturais da terra como candidatos à carreira eclesiástica, como se fazia no início da empresa missionária, o Geral provocou um esvaziamento dos colégios, que passaram a formar poucos alunos e cujos cursos aconteciam somente de tempos em tempos.

É possível afirmar, portanto, que a campanba pedagógica contrarreformista colocou em cena a pedagogia da vigilância por meio de um rígido controle sobre as letras e as práticas de instrução no período. Creio que, quando se instituiu essa rigidez, a partir do Concílio de Trento, o que aconteceu foi um enrijecimento dos modos de prescrever o que se deveria conhecer, a maneira como deveriam ser repassados os conteúdos e quem deveriam ser os sujeitos considerados capazes de aprender o que

17 De acordo com Soares (1995, p. 55), "são três as coisas que se perguntam em toda a disputa, 'se é ou não, o que é e como é”'. 
era digno de conhecimento. A intenção deste artigo foi, pois, aproximar o leitor dos fundamentos e da ambiência que provocou e tornou possíveis os embates do período.

\section{REFERÊNCIAS}

Assunção, Paulo. Negócios jesuíticos: o cotidiano da administração dos bens divinos. São Paulo: Edusp, 2004.

Castelnau-L'Estoile, Charlotte. Operários de uma vinha estéril: os jesuítas e a conversão dos índios no Brasil - 1580-1620. Tradução de Ilka Stern Cohen. Bauru: Edusc, 2006.

FARIA, Marcos Roberto de. As representaçóes de escola, ensino e aluno nas cartas de Manuel da Nóbrega, José de Anchieta e Antonio Blázquez (1549-1584). 2005. 170f. Dissertação (Mestrado em Educação: História, Política, Sociedade) - Pontifícia Universidade Católica de São Paulo, São Paulo, 2005.

A educação jesuítica e os conflitos de uma missão: um estudo sobre o lugar do jesuíta na sociedade colonial (1580-1640). 2009.314f. Tese (Doutorado em Educação: História, Política, Sociedade) - Pontifícia Universidade Católica de São Paulo, São Paulo, 2009. Hansen, João Adolfo. A sátira e o engenho: Gregório de Matos e a Bahia do século XVII. 2. ed. rev. São Paulo: Ateliê Editorial; Campinas: Editora da UNICAMP, 2004. Leite, Serafim da Silva. História da Companbia de Jesus no Brasil. Rio de Janeiro: Instituto Nacional do Livro, 1938-1949. $10 \mathrm{v}$.

\section{FONTES CONSULTADAS}

Archivum Romanum Societatis Iesu (ARSI). Brasilia Epistolae - Bras. . Lusitania Epistolae - Lus. . Congregationes Provinciarum-CP.

Monumenta Historica Societatis IESU (MHSI). Monumenta Brasiliae IV (1563- 1568). Roma: Via dei Penitenzieri, 20, 1960.

Soares, Cipriano. Arte de retórica. Três livros extraídos sobretudo de Aristóteles, Cícero e Quintiliano. Tradução de Silvério Augusto Benedito (Mimeografado). [1562] 1995. Parte integrante da dissertação de mestrado em literaturas clássicas, área de literatura latina, Faculdade de Letras da Universidade Clássica de Lisboa, Lisboa.

\section{SOBRE O AUTOR}

Marcos Roberto de Faria é doutor em educação pela Pontifícia Universidade Católica de São Paulo (PUC-SP). Professor da Universidade Federal de Alfenas (UNIFAL).

E-mail: marcosfaria07@yahoo.com.br 